\title{
Experiments and modeling of single plastic particle conversion in suspension
}

Nakhaei, Mohammadhadi; Wu, Hao; Grévain, Damien; Jensen, Lars Skaarup; Glarborg, Peter; Clausen, Sønnik; Dam-Johansen, Kim

Published in:

Fuel Processing Technology

Link to article, DOI:

10.1016/j.fuproc.2018.05.003

Publication date:

2018

Document Version

Peer reviewed version

Link back to DTU Orbit

Citation (APA):

Nakhaei, M., Wu, H., Grévain, D., Jensen, L. S., Glarborg, P., Clausen, S., \& Dam-Johansen, K. (2018).

Experiments and modeling of single plastic particle conversion in suspension. Fuel Processing Technology, 178, 213-225. https://doi.org/10.1016/j.fuproc.2018.05.003

\section{General rights}

Copyright and moral rights for the publications made accessible in the public portal are retained by the authors and/or other copyright owners and it is a condition of accessing publications that users recognise and abide by the legal requirements associated with these rights.

- Users may download and print one copy of any publication from the public portal for the purpose of private study or research.

- You may not further distribute the material or use it for any profit-making activity or commercial gain

- You may freely distribute the URL identifying the publication in the public portal 


\section{Supplementary material}

\section{Thermochemical properties of PE}

In this section, a short description of available thermochemical data related to $\mathrm{PE}$ is provided. The thermal conductivity of polyethylene reported in the literature lies in the range of $0.18-0.4 W \cdot m^{-1} \cdot K^{-1}$ for temperatures below $220^{\circ} \mathrm{C}$. In some studies, it is assumed that the thermal conductivity decreases as the temperature increases or the thermal conductivity of the solid state material is higher than the liquid state [1-4]. However, for some cases, the thermal conductivity is considered to be constant [5-7] or increase with the temperature [8].

The specific heat capacity of polyethylene is mostly considered to be higher when the material is in the liquid state than in the solid state. The reported values are in the range of $1.6-2.6 \mathrm{~kJ} . \mathrm{kg}^{-1} \cdot \mathrm{K}^{-1}$ for the solid state and $2.2-3.8 \mathrm{~kJ} \cdot \mathrm{kg}^{-1} \cdot \mathrm{K}^{-1}$ for the liquid state PE up to $400^{\circ} \mathrm{C}[5,7,9,12$.

The reported values for heat of melting of polyethylene material lie in the ranges of 54$218 \mathrm{~kJ} / \mathrm{kg}$ [10, 11, 13]. In the present study, the average measured heat of melting is equal to $207 \mathrm{~kJ} / \mathrm{kg}$ (see section 2 in supplementary material) which is close to the upper limit of the literature values. Some of the reported heats of melting and decomposition of PE material are presented in Table 1. The values used for heat of decomposition of PE are scattered widely in the range of $365-975 \mathrm{~kJ} / \mathrm{kg}$.

The decomposition kinetics that have been reported in the literature for polyethylene, based on the power law model, are summarized in Table 2. Most of the reported kinetics are of first order and are derived based on low heating rate experiments. According to Westerhout et al. [14], the first-order model is only applicable for a narrow conversion range, i.e. $70-90 \%$. Nevertheless, the first order model has been frequently used in the 
literature over wider conversion ranges.

The absorption of radiative energy of partly transparent particles depends on several parameters such as the incoming radiative wavelength, the thickness, etc. Tsilingiris [15] made calculations of the total transmissivity, $\tau$, (for all ranges of wavelengths) of thermoplastic materials with different thickness. According to the calculations and measurements carried out by Tsilingiris [15], for PE sheets with thicknesses of 0.1 and $0.5 \mathrm{~mm}$, around 75 and 43 percent, respectively, of the incoming radiative light is transmitted through the material. There are different values in the literature reported for the absorption coefficient. Caridi et

al. [16] have studied the transmission of light through different pure and impure polyethylene samples at various wavelengths. For the pure polyethylene material, they reported absorption coefficient values in the range of $271-3290 \mathrm{~m}^{-1}$ for incoming light wavelength in the range of 313-1064 $\mathrm{nm}$ (the dependency is inverse).

\section{DSC measurements of high density polyethylene samples}

The melting behaviour of high density polyethylene samples is studied using discovery DSC apparatus. The experiments are conducted for three heating rates of 5, 10, and 20 $\mathrm{K} / \mathrm{min}$. For each experiment, the sample is initially heated to $250^{\circ} \mathrm{C}$; afterwards it is cooled down to the environment temperature, and finally it is heated again to $250^{\circ} \mathrm{C}$ with the specified heating rate. The reported results in this section are based on the third cycle of the experiments. Depicted in Fig. 1 are the heat flows to the sample as a function of temperature for different heating rates. It can be observed that the peak of the heat flow reduces as the heating rate increases and instead, the peak would have a wider shoulder. The peak temperature is almost the same and around $127^{\circ} \mathrm{C}$ for all of the experiments. In order to calculate the heat of melting for each curve, a line connecting the corresponding heat flows at 35 and $150^{\circ} \mathrm{C}$ is drawn and the area enclosed between the curve and the line is calculated. For the heating rates of 5,10 , and $20 \mathrm{~K} / \mathrm{min}$, the calculated values of heat 
of melting are 209, 207, and $200 \mathrm{~kJ} / \mathrm{kg}$, respectively. A tendency of slight decrease in the heat of melting by increasing the heating rate can be observed. In the current study, the results from the DSC experiment with the heating rate of $10 \mathrm{~K} / \mathrm{min}$ is used, i.e. the heat of melting, the peak temperature as the melting point, and the kinetics of the first order melting reaction presented in Table 3 of the main manuscript.

\section{Particle dropping from the holding wire/thermocouple}

In this section, an overview of the observations and reasoning for particle droppage from the holding wire/thermocouple is provided. The molten thermoplastic materials are considered as non-Newtonian fluids and their viscosity is reduced by increasing the temperature or the applied shear rate [17]. The shear stress applied to a particle hanging from a holding wire depends on the particle mass. Furthermore, when the contact area of the particle with the hanging wire/thermocouple is larger, the overall maximum shear stress decreases (which leads to a more viscous plastic melt); also regardless of the viscosity, the thermoplastic particle has a less tendency for dropping from the holding wire/thermocouple. Accordingly, it can be stated that the point at which the particle starts to drop depends on both the particle temperature, the particle mass, and the particle holder.

When the particle is suspended using the thermocouple, the contact area between the particle and the thermocouple is higher compared to the holding wire. As a result, when the same particle is tested in similar reactor condition, the dropping of particle happens at an earlier time when the wire holder is used. This can be observed in Fig. 8 of the main manuscript which shows the temporal evolution of the particle center and surface temperatures suspended by the thermocouple and the wire, respectively. The delay in the particle droppage when it is suspended using the thermocouple in turn, postpones the start of decomposition. Another point to consider in the mentioned figure is that as a bigger hole is drilled in the particles for the measurement of the center temperature, the mass of these 
particles is around 1.3-3.0 $\mathrm{mg}$ smaller than the ones studied for the surface temperature measurement. This also affects the particle droppage to some extent.

In Fig. 8 of the main manuscript, considering the case when HDPE-1 and HDPE4 particles are suspended using the thermocouple, the center temperature at which the particles start to drop are different. For HDPE -1 particles, the dropping starts at around $300^{\circ} \mathrm{C}$ while for $\mathrm{HDPE}-4$ particles, it starts at around $200^{\circ} \mathrm{C}$; which indicates that heavier particles have a higher tendency to drop earlier than the lighter particles. It is interesting to mention that for both reactor temperatures, the ratio of the time at which the particle starts to drop from the thermocouple to the recorded melting time is nearly the same for the HDPE particles of the same size, i.e. around 2.3 and 1.8 for HDPE -1 and HDPE-4 particles, respectively. The mentioned behaviour shows that the particle dropping time depends on the particle size; but is weakly dependent on the furnace temperature. It should be noted that there is some degrees of uncertainty for the point at which the particle starts to drop from the wire/thermocouple. This process is captured qualitatively by human eye after analysis of the video images taken with a frequency of around 25 frames per second.

\section{The effects of particle holder on conversion of thermoplastic particles}

During each experiment of thermoplastic conversion in SPC, some moments after the particle center temperature reaches to the melting temperature, the particle starts to drop from the holding wire/thermocouple; and afterwards, it touches the hot particle holder. The time that is considered for particle droppage on the particle holder is equal to $1.7 \times$ melting time. This time is chosen based on the average dropping time according to the observations during the experiments.

In order to consider the effect of the particle holder on the decomposition process, it is assumed that when the particle is dropped down from the wire holder on the hot particle holder, the particle holder is at the same temperature as that of the gas. The maximum 
possible energy transfer between the particle and the particle holder is calculated assuming thermal equilibrium. Based on the remaining mass of the particle, the calculated value of energy transfer is reduced from the heat of decomposition. At the start of each experiment, the particle holder and the particle enter the reactor having an initial temperature reported in Table 3 of the main manuscript. During the process of initial heating, the cold particle holder most likely cools down the downstream gas and attenuates the convective heat transfer to the particle. Furthermore, as the particle holder has a low temperature, the particle receives less heat from radiation. The effect of transient heating of particle holder at the beginning of the experiment is taken into account by considering an exponential gas and wall temperature increase with the time constants of 1.55 and 1.4 seconds for EC-900C and EC-1100C reactor conditions, respectively. The mentioned time constants are based on averaged times that the holder starts to glow from the visual observations.

According to the visual observations during some of the experiments, a complicated gas flow field exists downstream of the particle holder. Shown in Fig. 2 are some examples of this complex flow. In all of the examples presented, at least one vortex is observed at the top of the particle holder with its axis parallel to the wire holder. When a particle is held on the wire (Fig. 2, bottom), the vortex is elongated over the particle.

In order to quantify the gas velocity downstream of the particle holder, simple CFD calculations of the reactor are carried out with and without the particle holder using ANSYS FLUENT 18.1. It is assumed that the fluid properties, e.g. density, viscosity, specific heat, etc., are constant and corresponding to the reactor condition EC-900C. The particle holder geometry in the CFD simulations is assumed to be a thin plate of $9 \mathrm{~mm}$ diameter composed of holes with a diameter of $0.1 \mathrm{~mm}$. The open area ratio of the plate, the ratio of open area to the total area, is approximately 0.35 . A spherical particle with a diameter of $3.87 \mathrm{~mm}$, the volume-equivalent diameter of $\mathrm{HDPE}-1$ particle, is placed at around $3 \mathrm{~mm}$ downstream of the perforated plate. 
The simulated flow patterns downstream of the particle holder as well as around the particle are depicted in Fig. 3. As the particle holder is added upstream of the particle, the flow velocity magnitude in the vicinity of the particle is significantly reduced and a vortex ring is formed around the particle.

In order to quantify the reduction of convective heat transfer to the particle due to the presence of the particle holder, the flow energy equation, decoupled from the momentum equations, is also solved. The gas flow temperature and the particle surface temperature are assumed to be fixed and equal to $900^{\circ} \mathrm{C}$ and $27^{\circ} \mathrm{C}$, respectively. The convective heat transfer to the particle is reduced around $38 \%$ after addition of the particle holder to the flow. By carrying out simple calculations using Eq. 8 of the main manuscript, it can be stated that the equivalent particle Reynolds number is reduced around 90\%. Accordingly, in the calculations of thermoplastic conversion in SPC using the detailed 1D model, it is assumed that the flow velocity that the particle senses is only $10 \%$ of the gas velocity at the center of the reactor.

\section{The numerical method for particle shrinking}

As mentioned before, the numerical cells move as the particle starts to decompose. In this section, the numerical method for particle shrinking is provided. In the numerical scheme, the calculation variables, e.g. temperature, specific heat, etc., are stored in the center of the numerical cells and the numerical cells are spaced with equal distance from each other. After the start of decomposition, in each time step, the updated diameter of the particle is calculated based on the new particle mass and the new positions of the cell centres are recalculated. An example of the movement of a numerical cell due to particle shrinkage in a time step is depicted in Fig. 4. The loss of mass usually happens in the outer layer of the particle where the temperature is higher; so as the shrinking happens, the inner cells should move toward the particle center. Due to this process, compared to the old time step, 
the cell may receive/lose some mass from/to the neighbouring cells shown as $d m^{-} / d m^{+}$in the figure. An energy equilibrium equation is solved to conserve the energy balance for the particle after shrinking. The new cell temperatures after applying this energy equilibrium can be calculated as,

$$
T_{i}^{\text {new }}=\frac{\left(m_{i}^{\text {old }}-d m^{+}\right) C p_{i} T_{i}^{\text {old }}+d m^{-} C p_{i-1} T_{i-1}^{\text {old }}}{\left(m_{i}^{\text {old }}-d m^{+}\right) C p_{i}+d m^{-} C p_{i-1}}
$$

where superscripts "new" and "old" correspond to the values after and before the calculation of shrinking effect in a time step. The subscripts " $i-1$ ", "i", and "i+1" correspond to variables belonging to cells numbers "i-1", "i", and "i+1", respectively. The energy balance of the whole thermoplastic particle during conversion is checked to make sure that the solution of energy equation is conserved.

\section{References}

[1] D. E. Kline, Thermal conductivity studies of polymers, Journal of Polymer Science 50 (154) (1961) 441-450. doi:10.1002/pol.1961.1205015413.

[2] K. Eiermann, K. Hellwege, Thermal conductivity of high polymers from -180C to 90C., Journal of Polymer Science 57 (165) (1962) 99-106. doi:10.1002/pol.1962. 1205716508 .

[3] X. Zhang, W. Hendro, M. Fujii, T. Tomimura, N. Imaishi, Measurements of the thermal conductivity and thermal diffusivity of polymer melts with the short-hot-wire method, International Journal of Thermophysics 23 (4) (2002) 1077-1090. doi:10.1023/A: 1016394104244.

[4] X. Zhang, M. Fujii, Measurements of the thermal conductivity and thermal diffusivity 
of polymers, Polymer Engineering and Science 43 (11) (2003) 1755-1764. doi : 10.1002/ pen.10148.

[5] T. Bluhm-Drenhaus, A. Becker, S. Wirtz, V. Scherer, A model for the devolatilisation of large thermoplastic particles under co-firing conditions, Fuel 101 (2012) 161-170. doi:10.1016/j.fuel.2012.05.041.

[6] C. Di Blasi, Linear pyrolysis of cellulosic and plastic waste, Journal of Analytical and Applied Pyrolysis 40-41 (1997) 463-479.

[7] C. Di Blasi, Transition between regimes in the degradation of thermoplastic polymers, Polymer Degradation and Stability 64 (3) (1999) 359-367. doi:10.1016/ S0141-3910(98)00134-7.

[8] S. Stoliarov, S. Crowley, R. Lyon, G. Linteris, Prediction of the burning rates of noncharring polymers, Combustion and Flame 156 (5) (2009) 1068-1083. doi:10.1016/j. combustflame.2008.11.010.

[9] V. Bares, B. Wunderlich, Heat capacity of molten polymers, J Polym Sci Part A-2 Polym Phys 11 (5) (1973) 861-873.

[10] S. Stoliarov, R. Walters, Determination of the heats of gasification of polymers using differential scanning calorimetry, Polymer Degradation and Stability 93 (2) (2008) 422427. doi:10.1016/j.polymdegradstab.2007.11.022.

[11] L. Cafiero, D. Fabbri, E. Trinca, R. Tuffi, S. Vecchio Ciprioti, Thermal and spectroscopic (TG/DSC-FTIR) characterization of mixed plastics for materials and energy recovery under pyrolytic conditions, Journal of Thermal Analysis and Calorimetry 121 (3) (2015) 1111-1119. doi:10.1007/s10973-015-4799-2. 
[12] C. Zhou, W. Yang, Effect of heat transfer model on the prediction of refuse-derived fuel pyrolysis process, Fuel 142 (2015) 46-57. doi:10.1016/j.fuel.2014.10.079.

[13] G. Agarwal, B. Lattimer, Method for measuring the standard heat of decomposition of materials, Thermochimica Acta 545 (2012) 34-47. doi:10.1016/j.tca.2012.06.027.

[14] R. Westerhout, J. Waanders, J. Kuipers, W. Van Swaaij, Kinetics of the lowtemperature pyrolysis of polyethene, polypropene, and polystyrene modeling, experimental determination, and comparison with literature models and data, Industrial and Engineering Chemistry Research 36 (6) (1997) 1955-1964. doi:10.1021/ie960501m.

[15] P. Tsilingiris, Comparative evaluation of the infrared transmission of polymer films, Energy Conversion and Management 44 (18) (2003) 2839-2856. doi:10.1016/ S0196-8904(03)00066-9.

[16] F. Caridi, L. Torrisi, A. Visco, Light transmission through polyethylene samples, Optics Communications 285 (6) (2012) 1199-1205. doi:10.1016/j.optcom.2011.10.029.

[17] A.-Y. Wong, J. Liang, Temperature and pressure effects on the melt index and melt density of high-density polyethylene, Journal of Materials Processing Tech. 43 (2-4) (1994) 293-304. doi:10.1016/0924-0136(94)90027-2.

[18] J. Frederick, W.J., C. Mentzer, Determination of heats of volatilization for polymers by differential scanning calorimetry, Journal of Applied Polymer Science 19 (7) (1975) 1799-1804. doi:10.1002/app.1975.070190702.

[19] V. Cozzani, C. Nicolella, L. Petarca, M. Rovatti, L. Tognotti, A fundamental study on conventional pyrolysis of a refuse-derived fuel, Industrial and Engineering Chemistry Research 34 (6) (1995) 2006-2020. doi:10.1021/ie00045a010. 
[20] S. L. Madorsky, Rates of thermal degradation of polystyrene and polyethylene in a vacuum, Journal of Polymer Science 9 (2) 133-156. doi:10.1002/pol.1952.120090203.

[21] S. Urzendowski, A. Guenther, Kinetic constants of polymeric materials from thermogravimetric data, Journal of Thermal Analysis 3 (4) (1971) 379-395. doi:10.1007/ BF02188645.

[22] S. Ciutacu, D. Fatu, E. Segal, On the thermal stability of some macromolecular compounds, Thermochimica Acta 131 (C) (1988) 279-284. doi:10.1016/0040-6031(88) $80081-9$.

[23] G. Darivakis, J. Howard, W. Peters, Release rates of condensables and total volatiles from rapid devolatilization of polyethylene and polystyrene, Combustion Science and Technology 74 (1-6) (1990) 267-281. doi:10.1080/00102209008951692.

[24] C. H. Wu, C. Y. Chang, J. L. Hor, S. M. Shih, L. W. Chen, F. W. Chang, On the thermal treatment of plastic mixtures of MSW: Pyrolysis kinetics, Waste Management 13 (3) (1993) 221-235. doi:10.1016/0956-053X(93)90046-Y.

[25] R. Knumann, H. Bockhorn, Investigation of the kinetics of pyrolysis of PVC by TGMS-analysis, Combustion Science and Technology 101 (1-6) (1994) 285-299. doi:10. $1080 / 00102209408951877$.

[26] H. Bockhorn, A. Hornung, U. Hornung, D. Schawaller, Kinetic study on the thermal degradation of polypropylene and polyethylene, Journal of Analytical and Applied Pyrolysis 48 (2) (1999) 93-109. doi:10.1016/S0165-2370(98)00131-4.

[27] P. Grammelis, P. Basinas, A. Malliopoulou, G. Sakellaropoulos, Pyrolysis kinetics and combustion characteristics of waste recovered fuels, Fuel 88 (1) (2009) 195-205. doi: $10.1016 / j . f u e l .2008 .02 .002$. 


\section{Tables}

Table 1: The literature reported values for heats of melting and decomposition of PE from DSC experiments.

\begin{tabular}{|c|c|c|c|c|}
\hline Reference & $\begin{array}{c}\text { thermoplastic } \\
\text { type }\end{array}$ & $\begin{array}{l}\text { heating } \\
\text { rate } \\
(K / m i n)\end{array}$ & $\begin{array}{l}\text { heat of } \\
\text { melting } \\
(k J / k g)\end{array}$ & $\begin{array}{c}\text { heat of de- } \\
\text { composition } \\
(k J / k g)\end{array}$ \\
\hline Stoliarov et al. [10] & $\mathrm{PE}$ & 5 & $218 \pm 18$ & $920 \pm 120$ \\
\hline $\begin{array}{l}\text { Frederick JR and Mentzer } \\
18\end{array}$ & $\mathrm{PE}$ & 10 & - & $665 \pm 54$ \\
\hline Cozzani et al. [19] & $\mathrm{PE}$ & 10 & - & 650 \\
\hline Cafiero et al. [11] & $\mathrm{PE}$ & 10 & $97 \pm 2$ & $975 \pm 8$ \\
\hline Agarwal and Lattimer [13] & HDPE & 20 & 135 & $365-556$ \\
\hline Agarwal and Lattimer 13 & LDPE & 20 & 54 & $428-575$ \\
\hline
\end{tabular}


Table 2: The decomposition kinetics of polyethylene reported in the literature.

\begin{tabular}{|c|c|c|c|c|c|c|}
\hline Reference & material & $\begin{array}{l}\text { temperature } \\
\text { range }\left({ }^{\circ} \mathrm{C}\right)\end{array}$ & order & $\begin{array}{l}\text { pre-exponential } \\
\text { factor }\left(s^{-1}\right)\end{array}$ & $\begin{array}{c}\text { activation } \\
\text { energy }(\mathrm{J} / \mathrm{mol})\end{array}$ & $\begin{array}{c}\text { experimental } \\
\text { condition }\end{array}$ \\
\hline Madorsky (1952) 20] & $\mathrm{PE}$ & $385-405$ & 1 & $5.20 \times 10^{11}$ & $2.01 \times 10^{5}$ & $\begin{array}{c}\text { high heating rate } \\
\text { pyrolysis }\end{array}$ \\
\hline \multirow[t]{2}{*}{$\begin{array}{l}\text { Urzendowski and } \\
\text { Guenther (1971) 21] }\end{array}$} & HDPE & $410-495$ & 1 & $1.19 \times 10^{20}$ & $3.20 \times 10^{5}$ & $\begin{array}{l}\text { TGA with } 5-10 \\
K / \min \end{array}$ \\
\hline & LDPE & $380-480$ & 1 & $9.63 \times 10^{19}$ & $3.03 \times 10^{5}$ & $\begin{array}{l}\text { TGA with } 5-10 \\
K / \min \end{array}$ \\
\hline \multirow[t]{2}{*}{$\begin{array}{l}\text { Ciutacu et al. (1988) } \\
22]\end{array}$} & $\mathrm{PE}$ & $230-380$ & 1 & $1.80 \times 10^{3}$ & $6.65 \times 10^{4}$ & $\begin{array}{c}\text { TGA with } 2.5-10 \\
K / \min \end{array}$ \\
\hline & $\mathrm{PE}$ & $380-550$ & 1 & $2.60 \times 10^{6}$ & $1.22 \times 10^{5}$ & $\begin{array}{c}\text { TGA with } 2.5-10 \\
K / \min \end{array}$ \\
\hline $\begin{array}{l}\text { Darivakis et al. (1990) } \\
23\end{array}$ & $\mathrm{PE}$ & $450-775$ & 1 & $1.00 \times 10^{13}$ & $2.08 \times 10^{5}$ & $\begin{array}{l}\text { flash pyrolysis at high } \\
\text { heating rate of } 1000 \\
K / s\end{array}$ \\
\hline \multirow[t]{2}{*}{ Wu et al. (1993) 24] } & HDPE & $325-500$ & 0.74 & $9.30 \times 10^{13}$ & $2.34 \times 10^{5}$ & $\begin{array}{l}\text { TGA with } 1-5.5 \\
K / \min \end{array}$ \\
\hline & LDPE & $300-525$ & 0.63 & $1.20 \times 10^{12}$ & $2.06 \times 10^{5}$ & $\begin{array}{l}\text { TGA with } 1-5.5 \\
K / \min \end{array}$ \\
\hline $\begin{array}{l}\text { Bockhorn and } \\
\text { Knümann } \\
25\end{array}$ & $\mathrm{PE}$ & $200-600$ & 0.81 & $7.20 \times 10^{13}$ & $2.59 \times 10^{5}$ & \\
\hline \multirow[t]{3}{*}{$\begin{array}{l}\text { Westerhout } \\
\text { (1997) 14 }\end{array}$} & HDPE & $400-450$ & 1 & $1.90 \times 10^{13}$ & $2.20 \times 10^{5}$ & $\begin{array}{c}\text { TGA at isothermal } \\
\text { condition }{ }^{\circ} \mathrm{C}\end{array}$ \\
\hline & LDPE & $400-450$ & 1 & $1.00 \times 10^{15}$ & $2.41 \times 10^{5}$ & $\begin{array}{c}\text { TGA at isothermal } \\
\text { condition }{ }^{\circ} \mathrm{C}\end{array}$ \\
\hline & LDPE & $400-450$ & 1 & $9.80 \times 10^{11}$ & $2.01 \times 10^{5}$ & $\begin{array}{c}\text { TGA at isothermal } \\
\text { condition }{ }^{\circ} \mathrm{C}\end{array}$ \\
\hline $\begin{array}{l}\text { Bockhorn et al. } \\
(1999)[26]\end{array}$ & $\mathrm{PE}$ & $410-460$ & 1 & $1.00 \times 10^{16}$ & $2.68 \times 10^{5}$ & $\begin{array}{l}\text { isothermal using a } \\
\text { gradient free reactor }\end{array}$ \\
\hline $\begin{array}{l}\text { Stoliarov et al. (2009) } \\
8\end{array}$ & HDPE & $420-525$ & 1 & $\begin{array}{r}4.80 \times 10^{22} \\
12 \\
\end{array}$ & $3.49 \times 10^{5}$ & $\begin{array}{l}\text { TGA with } 1-30 \\
\qquad / \min \end{array}$ \\
\hline \multirow[t]{2}{*}{$\begin{array}{l}\text { Grammelis et } \\
(2009)[27]\end{array}$} & HDPE & $200-650$ & 1 & $4.50 \times 10^{28}$ & $4.45 \times 10^{5}$ & TGA with $20 \mathrm{~K} / \mathrm{min}$ \\
\hline & LDPE & $200-650$ & 1 & $1.40 \times 10^{28}$ & $4.37 \times 10^{5}$ & TGA with $20 \mathrm{~K} / \mathrm{min}$ \\
\hline
\end{tabular}




\section{Figure Captions}

Figure 1. The heat flow required for melting (and heating) of HDPE samples as a function of temperature based on heating rates of 5,10 , and $20 \mathrm{~K} / \mathrm{min}$ from DSC experiments.

Figure 2. Examples of moments showing the complex gas flow downstream of the particle holder. Top pictures: last moments of HDPE particles conversion with the particle holder used in the current study. Bottom pictures: devolatilization of spherical pine wood particles with a diameter of approximately $6.2 \mathrm{~mm}$ using a bigger particle holder. The reactor temperature is the same as that of the EC-1100C but with a higher oxygen concentration (approximately $10 \%$ vol. dry).

Figure 3. The flow stream lines as well as the velocity contours from the CFD simulations of SPC with (left) and without (right) the particle holder. The flow properties are similar to the reactor condition of EC-900C.

Figure 4. The movement of a numerical cell during particle shrinking due to decomposition in a time step. 
Figures

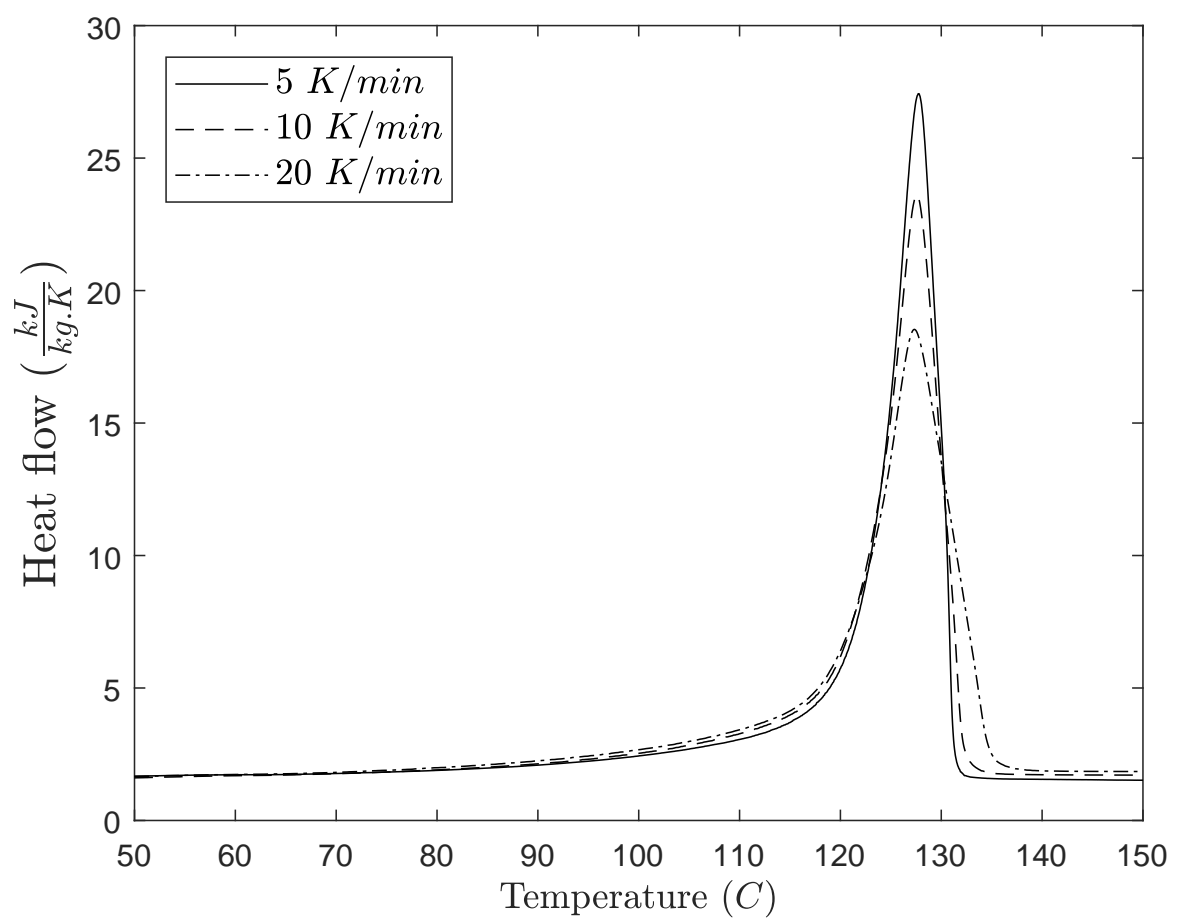

Figure 1: The heat flow required for melting (and heating) of HDPE samples as a function of temperature based on heating rates of 5,10 , and $20 \mathrm{~K} / \mathrm{min}$ from DSC experiments. 

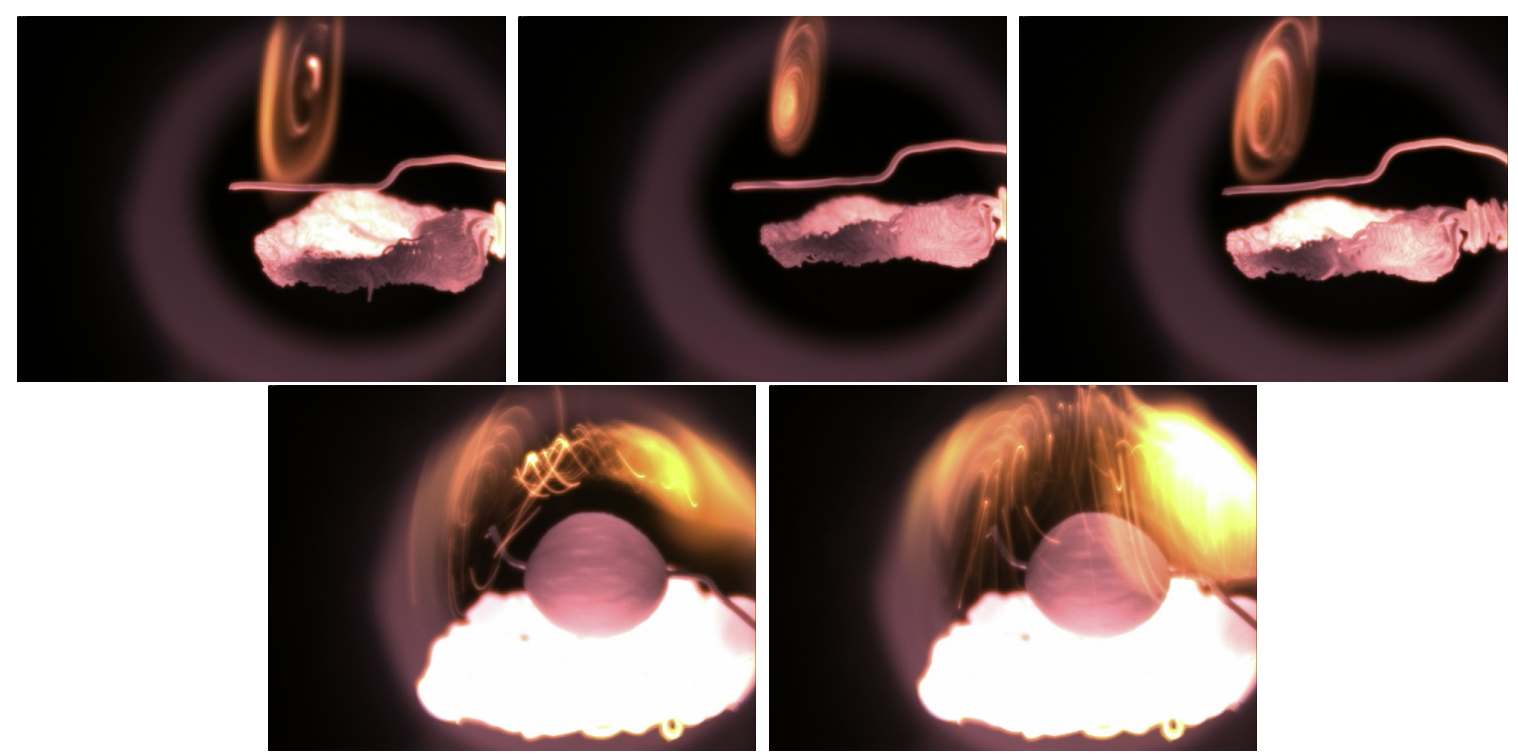

Figure 2: Examples of moments showing the complex gas flow downstream of the particle holder. Top pictures: last moments of HDPE particles conversion with the particle holder used in the current study. Bottom pictures: devolatilization of spherical pine wood particles with a diameter of approximately $6.2 \mathrm{~mm}$ using a bigger particle holder. The reactor temperature is the same as that of the EC-1100C but with a higher oxygen concentration (approximately $10 \%$ vol. dry).

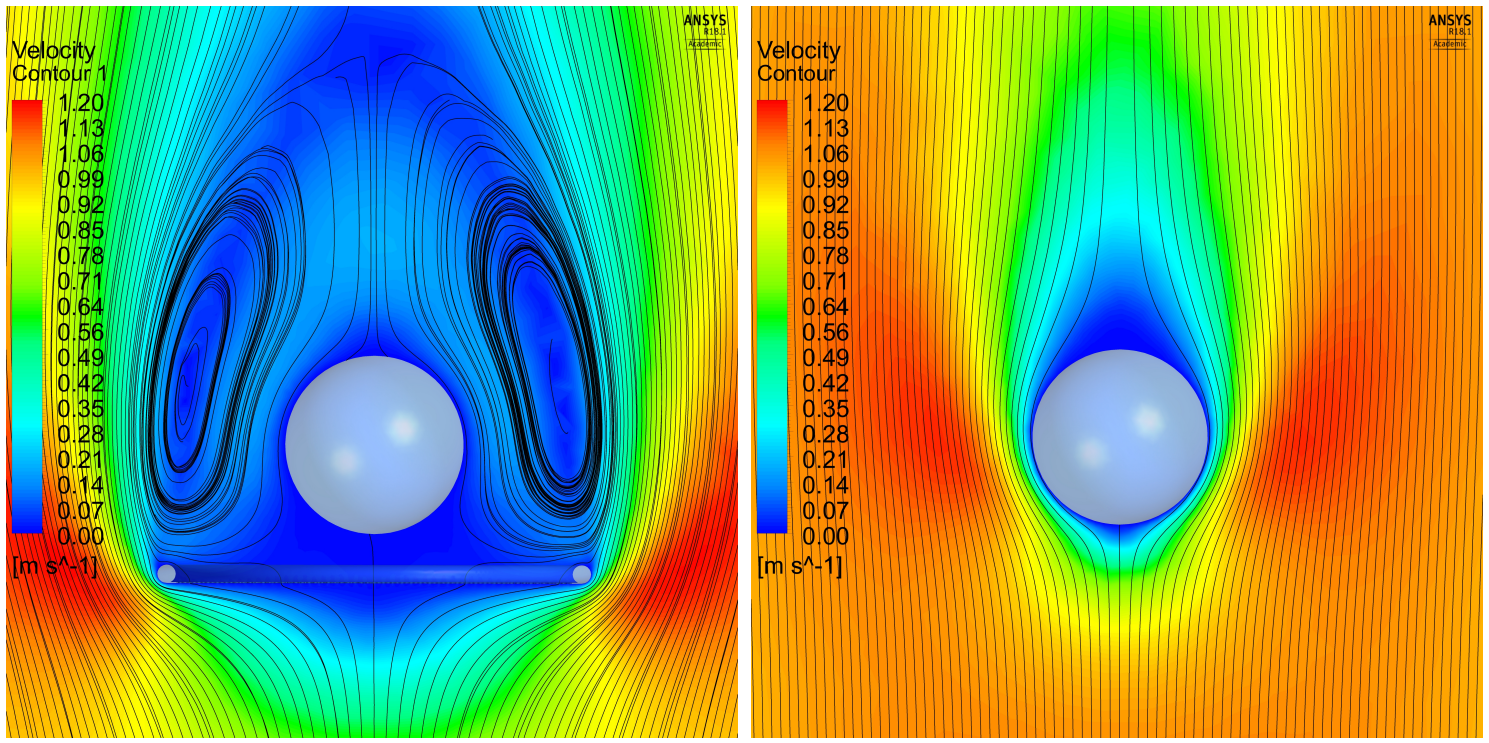

Figure 3: The flow stream lines as well as the velocity contours from the CFD simulations of SPC with (left) and without (right) the particle holder. The flow properties are similar to the reactor condition of EC-900C. 


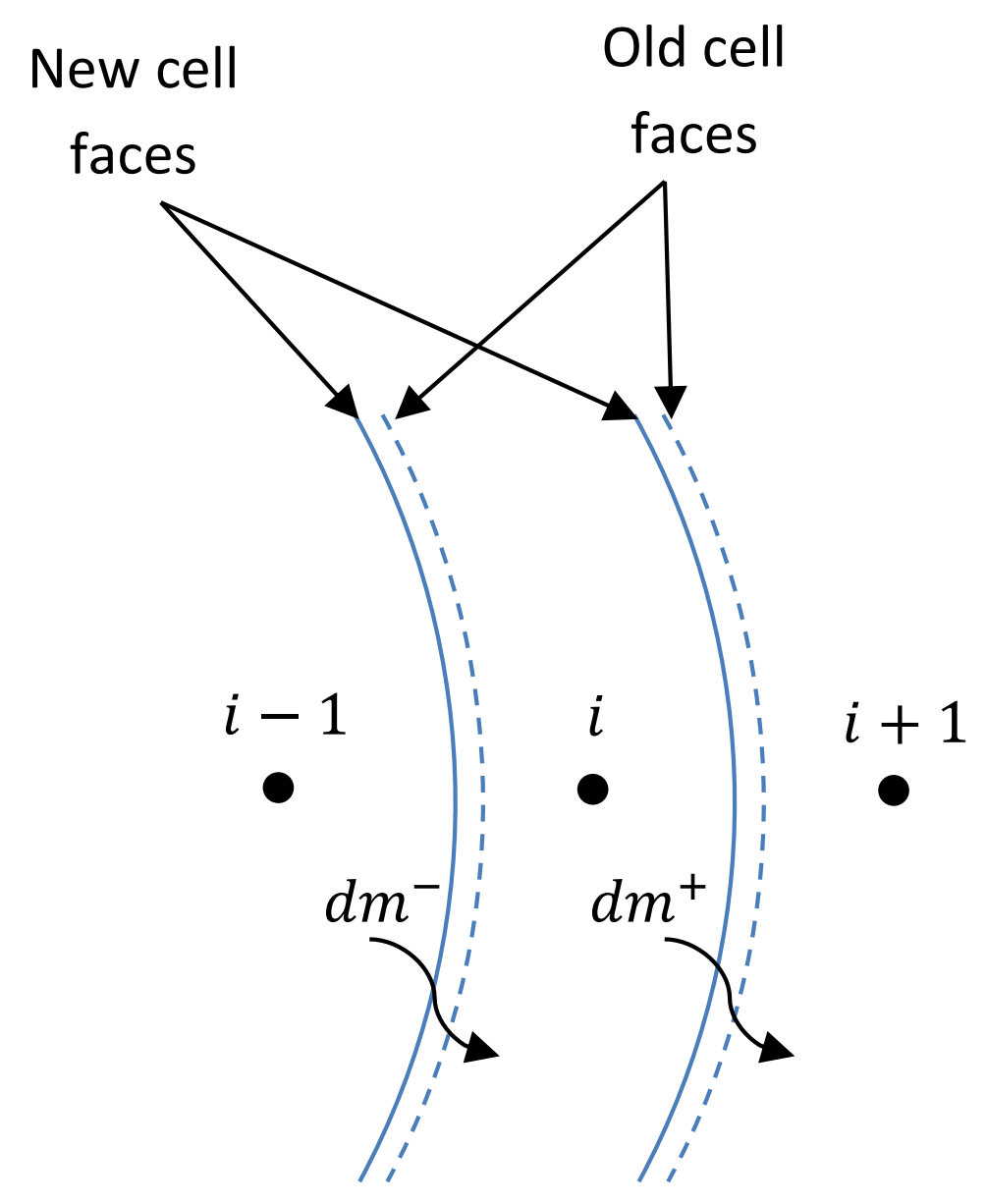

Figure 4: The movement of a numerical cell during particle shrinking due to decomposition in a time step. 